Volume 3

Number 2 December

Article 1

$12-31-2019$

\title{
Foreword from Handling Editor - 6th Edition
}

Astari Dwiranti

astari.dwiranti@sci.ui.ac.id

Follow this and additional works at: https://scholarhub.ui.ac.id/ajce

Part of the Social and Behavioral Sciences Commons

\section{Recommended Citation}

Dwiranti, Astari (2019). Foreword from Handling Editor - 6th Edition. ASEAN Journal of Community Engagement, 3(2).

Available at: https://doi.org/10.7454/ajce.v3i2.1070

Creative Commons License

(c) (i) ()

This work is licensed under a Creative Commons Attribution-Share Alike 4.0 License.

This Front Matter is brought to you for free and open access by the Universitas Indonesia at ASEAN Journal of Community Engagement. It has been accepted for inclusion in ASEAN Journal of Community Engagement. 


\section{Foreword from Handling Editor - ${ }^{\text {th }}$ Edition}

We are delighted to present the $6^{\text {th }}$ edition of AJCE, published in December 2019. We have selected eight of the best articles for this edition, consisted of five Research Articles, one Review Article, and two Case-Based Articles. These articles presented the valuable and interesting information with the broad ranges covering three sub-themes, i.e. education (parenting, urban community housing, assessment training, revolution 4.0-related teaching method, climate change), Economy (entrepreneurship capacity building), and Health (smartphone application for quality assurance).

We want to express our thanks to the reviewers who gave inputs and contributions to improve the quality of the articles. Our greatest thanks are also due to Azhar Firdaus for helping us with the publication process and to the Research and Innovation Management Office Universitas Indonesia (KPPRI UI) for providing a journal development grant, mini-symposium supports, and proofread assistance through Enago. Finally, we hope that readers enjoy the articles that we present in this edition.

Dr. Astari Dwiranti

Handling Editor of AJCE

Email: astari.dwiranti@ sci.ui.ac.id 